\title{
Neoclassical Realism and Foreign Policy Analysis - A Possible Way of Integration?'
}

\begin{abstract}
The main goal of the article is to discuss whether neoclassical realism (NCR), described as the most recent realist research programme might be perceived as a fruitful way of integrating IR theory with the assumptions of foreign policy analysis (FPA). Consequently, the research question that has to be answered, is whether the NCR has succeeded as a new research programme developed as an attempt to give the Waltzian theory more explanatory power. The article starts with a critical analysis of the main assumptions of the NCR, after which it focuses on FPA defined as a subdiscipline of IR. The third part of the text draws the attention to the neoclassical realism's integration of 'intervening variables' that bring FPA insights into the realist theoretical paradigm. It is argued that apart from numerous theoretical flaws, there is still a possible way to develop its theoretical depth through careful borrowing from FPA.
\end{abstract}

Keywords: neoclassical realism, neorealism, foreign policy analysis, systemic pressures, unit-level variables, analytic eclecticism

After all, there is no 'truth' out there waiting for discovery by one all-embracing theory. We are, therefore, in the business of dealing with competing theories and explanations, and in this light FPA has aided, and can continue to aid, the study of international relations.

Steve Smith (1986, p. 25)

The article draws the readers' attention to the relation between neoclassical realism (NCR) and selected theoretical assumptions associated with foreign policy analysis (FPA), which, according to some scholars' opinion, over the last 25 years has been largely ignored by almost all the IR theories. Therefore, Juliet Kaarbo (2015, pp. 189-215) emphasized that the current IR is marked by a paradox re-

For many helpful comments and suggestions, I would like to thank Stefano Guzzini from the Danish Institute for International Studies and the Uppsala University. 
lated to the role of domestic level factors. ${ }^{2}$ In spite of incorporating some decision-making concepts, (like state motives, perceptions, domestic political institutions, public opinion, and political culture etc.), much of IR theory ignores the development of FPA research. The opinion of this author suggesting that, 'domestic politics and decision-making processes are simultaneously everywhere and nowhere' (Kaarbo, 2015, p. 189), has drawn my attention not only to possibilities offered by the NCR, but also to some challenges resulting from this research programme and its potential connections with FPA.

The main goal of the presented article is to discuss whether the NCR, described frequently as the most recent realist research programme (the newest realism), is a fruitful and seminal way of integrating IR theory with FPA assumptions. In spite of being created as a kind of theoretical promise and a way forward after the critique of the neorealism, the NCR (or its adherents) has to show that the criticism resulting from the 'dizzy mixture' of factors operating at both systemic and domestic levels can be overcome. Consequently, the research question I want to answer here is whether the neoclassical realism has succeeded as a new research programme developed as a result of an attempt to give the Waltzian theory more explanatory power. As the version of realist theory proposed by him turned out to be too sparse and underspecified, some scholars have considered it as being in need of elaboration. Consequently, they started to add variables operating at domestic level and transforming systemic pressures and in this way tried to develop some kind of a new subparadigm (Narizny, 2017, pp. 159161). The result of this elaboration was the realist (neoclassical realist) version of a theory of foreign policy that I want to discuss below. Additionally, I want to explore whether the NCR, according to the opinion of Valerie Hudson (2016, pp. 32-33), is truly a seminal way of bridging IR and FPA.

The structure of the article is as follows. Firstly, I will lay out the core assumptions of neoclassical realism which will be presented together with the crit-

In the late of 1990s some IR theorists were working on advancing theories or research programmes focusing not only on the structure of international system, but also incorporating domestic politics. Firstly, Andrew Moravcsik (1997, pp. 513-553) developed a liberal theory that makes societal preferences the foundation of state behaviour. Secondly, Gideon Rose (1998, p. 146) pointed out that a few of books published during the last decade of the $20^{\text {th }}$ century successfully integrated systemic pressures and factors operating at the state level. Consequently, he called this new research programme 'neoclassical realism'. Although both of the above mentioned theories focus on the problem of combining different levels of analysis, the essential distinction between them is still significant. The liberal theory presented by Moravcsik is a bottom-up, domestic society-based theory that incorporates systemic variables, whereas the neoclassical realism is described as a top-down, international system-based theory that integrates factors operating at the state level (Narizny, 2017, pp. 155-156). Yet, both of them are considered as a way of involving domestic pressures and crossing different levels of analysis. 
icism of this research programme. I will stress that developing a foreign policy theory on the basis of neorealism could be considered as a confusing and complex project not only because of all the difficulties of linking structural pressures of the international systems with domestic variables, but also because of all the difficulties of merging two different logics of theory building and tension between different philosophies of science represented by FPA and structural realism (Weaver, 2009, pp. 201-221). I will point out that although FPA assumptions might offer a complementarity to a NCR-based analysis of state's action, one has to carefully assess or evaluate this programme as it might lead to some methodological errors, mainly due to its lack of internal coherence. By going beyond a recognition of domestic structure and incorporating many different intervening variables, i.a. the role of perception or political leadership, neo-classical realism seems to offer much more than only an undifferentiated depiction of the state that still remains one of its main characteristics. Nonetheless, one has to also mention that the way of creating the research programme of neoclassical realism takes the systemic assumptions for granted and asks only the question - how do states respond to them (Wæver, 2009, pp. 213-214) which could cause some problems regarding the issue of theory building which will be also discussed. What is more, adherents of the NCR have incorporated myriad of intervening variables which, according to the main assumptions of the proposed programme, are transforming the systemic pressures. However, without close attention to the paradigm boundaries, the incorporation of infinite number of intervening domestic factors might lead to serious methodological errors and as a consequence to coming back to the situation before the Waltz's conception. In the second part of the article, I will draw the attention to the position of FPA that is not fully acknowledged as part of IR theories as well as to its possibilities to engage with an ongoing dialogue with the discipline. Once these issues have been elucidated, the third and main part of the article will draw the attention to the neoclassical realism's integration of 'intervening variables' that bring FPA insights into the realist theoretical paradigm. In this part of the text I will focus on the balance of threat theory of Michael Walt and the assumptions regarding the role of perception formulated by William Wohlforth. This part also implies that neo-classical realism might develop its greater theoretical depth through careful borrowing from FPA. Finally, I will conclude that the possibility of bridging the NCR with assumptions commonly ascribed to FPA might lead to a very interesting kind of eclectic scholarship which consequently could help both the mainstream IR theories to integrate domestic level variables and theories of foreign policy to gain a structural dimension.

Additionally, what I am going to discuss and show in this article is that, apart from numerous ambiguities that the NCR has caused, the possibility of linking de- 
cision-making factors and conception of agency that are mostly ascribed to FPA with the assumptions of some of the 'mainstream' IR theories focused largely on the third (structural) level of analysis might be perceived as a type of remedy for current challenges and future problems of the IR discipline. Consequently, this kind of 'theoretical dialogue' should contribute to some kind of ontological reorientation within the discipline, which is currently facing calls for 'the end of IR theory' (Dunne, Hansen, Wight, 2013, pp. 405-425). Theoretical and methodological pluralisms, considered as a result of the 'great debates' lasting since the inception of the discipline and described by many scholars as causing disputes and stopping theoretical development, have caused the need for a deeper reflection on the possible progress of the international relations scholarship. Therefore, a seminal and well considered research programme that offers a possibility of linking systemic pressures with domestic factors might be considered as a beneficial enterprise.

I am also aware of the fact that focusing on the only one of IR theories is a very modest contribution to the academic debate, however I have to bear in mind all the restrictions typical for journal publications as well as the very specific topic of this issue. Nevertheless, by showing this way of engaging FPA with IR theory, I hope to stress that despite the problems generated by 'paradigmatic wars', we cannot abandon meta-theoretical debates. The latter, however, might lead to some kind of analytical engagement of IR theorists. As John J. Mearsheimer and Stephen M. Walt (2013, pp. 427-457) pointed out in their already very famous article, in order to achieve progress within the discipline and produce cumulative knowledge, we have to focus on refining existing theories and developing new ones as well as to engage in theoretical debates and privilege theory as we did before. As IR scholars we cannot focus on 'simplistic hypothesis testing', but should make an effort to create and refine theories or use theory to guide empirical research. According to the authors, focusing only on hypothesis testing, although reflecting a long-standing desire to professionalize the discipline might lead to misspecified empirical models, misleading measures of key concepts and consequently unsatisfying empirical findings (2013, pp. 438-49). Additionally, they called for a more diverse and plural intellectual community of different research traditions (2013, p. 430).

This assumption corresponds with guidelines formulated by Rudra Sil and Peter Katzenstein (2010, pp. 411-343) and referring to eclectic scholarship defined, however not directly, as a form of theoretical pluralism. The authors stressed that it is not only based on strong theoretical foundations, but also consistent with the ethos of pragmatism. Although they did not focus on FPA, I claim that to some extent their assumptions are present in FPA. Consequently the FPA-IR relation might be perceived as a kind of eclectic scholarship as well. All the three guidelines that are required by this kind of study are also fulfilled by FPA. 
Firstly, open-ended problem formulation (one of the three criteria) is a very important characteristic of almost all FPA research that does not look for univariate explanations with one single dominant theory. FPA scholars are less engaged in theoretical debates and their primary purpose is not to defend the core postulates of a theory, but rather to focus on more useful empirical work. FPA has never been organized or divided into different and incommensurable schools of thoughts, but rather looking for solutions of empirical problems.

Secondly, in order to satisfy the second marker, the eclectic scholarship has to be middle-range in scope and make use of 'multiple mechanisms and logics drawn from more than one paradigm' (Sil, Katzenstein, 2010, p. 415). Since the mid-1960s James Rosenau (1966, pp. 27-92) has encouraged FPA scholars to focus on actor-specific theories that mediate between grand principles and the complexity of reality. That was a step towards Robert Merton's concept of middle range theory. Obviously, that is not enough to qualify this attempt as an eclectic scholarship, however some recent works offer not only middle-range theory development, but also applying of multiple theories. A very good example of making use of multiple theoretical mechanisms is the article of William Flanik (2011, pp. 361-447) who uses the concept of 'metaphorical framing' borrowed from cognitive linguistics in order to combine assumptions of cognitive foreign policy analysis with social constructivism. In this way he blends not only FPA with IR theory, but also two different research programmes. Consequently, his adoption of 'metaphorical framing' is mutually beneficial for FPA and IR, as it translates different concepts and brings two different levels of analysis. What is more, his aim is (as he mentioned in the title) 'to bring FPA back home' (Flanik, 2011, p. 361) that clearly shows that FPA has always been close to the IR.

Finally, according to the practical engagement (third marker of analytical eclecticism), one has to stress that FPA has always been less engaged in philosophical deliberating, but rather focused on practical research that could be afterwards explained to the public opinion. Additionally, FPA scholars have frequently been engaged in practical issues and focused on doing research not only for political institutions, but also intelligence agencies - for instance, Robert Jervis has been consulting for the CIA with regard to issues of threat perception.

Linking IR theories with FPA research might be considered as a kind of movement toward analytical eclecticism as it does not require theoretical synthesis and at the same time a voluntary theoretical convergence of some scholars upon new foundational principles, but offers a possible foundation for theoretically integrative and methodologically pluralist research. Yet, one has to mention here that the proposed task seems to be easy, but in fact is not so straightforward, what I am also going to show in the following parts of the article. 


\section{Neo-classical realism - a way forward or backwards?}

The neo-classical realism (NCR), frequently described as one of the most surprising theoretical developments emerging from the current IR, has been mainly derived from a critique of neorealism ${ }^{3}$ formulated by representatives of this paradigm. ${ }^{4}$ Various realists have resigned from explaining states' behaviour by referring to system-level variables only and started to construct a new variant of the theory that will be able to explain why under the same systemic pressures states act differently or simply not do what the theory predicts (Waltz, 1979; Wivel, 2005). A growing number of scholars (incl. Snyder, 1991; Wohlforth, 1993; Zakaria, 1998; Schweller, 2004) have stressed the importance of combining systemic and unit-level variables. Thus, they did not reject the systemic explanations, but tried to show their incompleteness. As a consequence, all the above mentioned realists underlined that the systemic pressures had to be supplemented by some domestic variables including e.g. the risk perception, political leadership, domestic institutions etc. In 1998 Gideon Rose termed this branch of realism 'neo-classical realism'. In the article Neoclassical Realism and Theories of Foreign Policy he stressed its connections with assumptions typical for classical realism of i.a. Hans Morgenthau. Neo-classical realists reached back to classical realism's toolkit for arguments or theories providing better foreign policy analysis. However, by using the prefix neo-, Rose (1998, pp. 144-172) showed that this version of realist paradigm is different from neorealism of Kenneth Waltz. According to Rose, adherents of NCR argue that 'the scope and ambition of a country's foreign policy is driven first and foremost by its place in the international system and specifically by its relative material power capabilities' $(1998$, p. 146). That is the reason of calling them realists. However, all the systemic pressures are translated through intervening variables situated at the unit level - and that is why they are neoclassical. As Jeffrey W. Taliaferro (2006, pp. 464-495) stressed, in order to study states' foreign policy in the way formulated by neo-classical realists, one should pay attention not only to analytical strengths of neo-realists such as Waltz

Neorealism, frequently termed also as structural realism was developed by Kenneth Waltz, who translated core classical realist ideas into a deductive, top-down theoretical framework and at the same time provided realism with self-conscious scientism. He stressed that the features of the overall system of states affect their interactions. The ordering principle of international system is anarchy that leads to powerful competitive pressure and war, regardless of internal politics of states (Waltz, 1979).

4 The second branch of the critique has been formulated by neoliberal institutionalists and representatives of social constructivism who stressed that apart from systemic pressures there are also many other factors influencing states' behaviour, like i.a.: society's preferences or a set of ideational factors (norms, ideas, beliefs or identities) operating both within the state and the international system. 
or Robert Gilpin, but also to analytical power of unit level studies of classical realists such as Morgenthau, Henry Kissinger or Arnold Wolfers. ${ }^{5}$

However, one has to mention here that the term 'neoclassical realism' formulated by Rose regarded several works published in the 1990s that collectively constitute to some extent a coherent school of thought. The main feature of this school was an integration of factors operating at different levels of analysis, however, it has to be pointed out very clearly that each scholar representing the NCR was focused on a different set of domestic factors transforming the pressures of international system. This situation makes the picture of the NCR quite complicated. One might even suggest that adherents of this research programme (or subparadigm) would see a green light 'for the incorporation of any sort of domestic factor [...] without constraint' (Narizny, 2017, p. 170). What makes the picture even more complex is the fact that Rose distinguished only two kinds of unit-level intervening variables (perceptions of relative power dynamics and the ability of the state to mobilize resources) and suggested that the proposed programme is neoclassical realism (Rose, 1998, pp. 167-168) which is literally not true. The programme that he described is rather a kind of different set of theories under a broad umbrella with only one distinction, namely a mixture of systemic pressures with domestic politics with a strong believe that the first matter more. In his somehow famous article Rose did not formulate a set of neoclassical realist assumptions that would identify the research programme. He just pointed out that it is a kind of attempt of integrating systemic and unit-level factors, but without even defining a way of how to engage domestic politics with systemic pressures and how to distinguish it from liberal proposal of mixing these two levels of analysis (Narizny, 2017, pp. 170-171).

The first attempt to identify neoclassical realism as a deductive theoretical structure that resembled the proposition of Waltz, Moravcsik or Alexander Wendt, was realized by Steven E. Lobell, Norrin M. Ripsman and Jeffrey W. Taliaferro in their work from 2009 Neoclassical Realism, the State, and Foreign Policy. They defined neoclassical realism in paradigmatic terms, but called it a research programme - not a theory. The core assumptions of it are based on two guidelines. Firstly, the authors resigned from identifying states' motives and stressed that every work applying the NCR should define its baseline from several realist options: offensive realism, defensive realism, balance of threat theory, hegemonic theory etc. Secondly, four categories of intervening variables were defined: cognition, strategic culture, state-society relations and domestic insti-

The difference in their understanding of human nature is however worth of noting here. All of them saw human nature as static, whereas both NCR's assumptions and FPA research see it as changing, dynamic and influenced by many different factors. 
tutions (Lobell, Ripsman, Taliaferro, 2009, pp. 67-68). Finally, the authors identify and describe conditions under which certain variables matter more than others. The most significant in the assumptions proposed by them is the fact that they did not exclude any variable either did not formulate any constrains of the possibilities of applying them. However, the main problem of the proposed assumption regards systemic pressures, because the authors did not define their influence on states' behaviours. By stressing that each neoclassical realist work could in fact define on which realist subparadigm it is based, there is no need to perceive the systemic pressure as an important factor. As a consequence, if the system constraints are not important and much depends on the choice of theoretical baseline, than there is no necessity to suggest that neorealism is a part of the NCR. It is only its baseline. Finally, this might imply that the programme of neoclassical realism is in fact not a descendant of neorealism, but rather a kind of eclectic scholarship which additionally includes factors typical for FPA.

The essence of the NCR is that unit-level (domestic) variables are influencing states' effectiveness of responding to the international system incentives. The systemic pressures are not (as Waltz claimed) immediately transformed into states' actions, but the translation process is a very complex and indirect one. Moreover, the domestic variables are the central piece of this translation chain. Consequently, the international system is perceived as not the only one, yet still very important, of foreign policy constraints being faced by countries. According to Waltz, its theory lists a set of international system constraints that are generated by different (bi-, uni- or multipolar) system types. Nevertheless, his critics stressed that the theory does not explain how the systemic opportunities (pressures) are used by different states and which factors determine their employment. It does not answer the question whether opportunities offered by the international system will be taken by states in an appropriate way (however Waltz did not want his theory to do this). Therefore, one cannot predict states' behaviour according to their systemic positions. The power distribution within the international system might bound grand strategy, but, according to the NCR, its implementation cannot by inferred from the system level of analysis. The implementation of the strategy through decisions taken by foreign policy executives is based on threat assessment, risk, mobilization of domestic resources, including public support etc. The unit-level variables might constrain or facilitate the states' abilities to respond to the systemic imperatives (Lobell et al., 2009, p. 4). The anarchy of the international system (viewed as one of the main characteristics of neorealism) is therefore only a permissive condition rather than one single independent casual force (Walt, 2002, p. 211). As a consequence, one may assume that the NCR seeks to rectify the imbalance between 
the general and the particular or, in other words, tries to combine different levels of analysis. Its most important task is to combine elements of different level of analysis and give them explanatory power. Moreover, apart from the attempt of systemic and unit level combination, the NCR tries to mix the material and ideational ontology. The exemplary domestic variables mentioned above clearly demonstrate that the NCR refers not only to the material reality, but also to non-material factors like the role of perception. As it will be showed in next sections, these two very important features of the NCR have made the theory come under siege.

It has to be also mentioned here, that although the NCR might be nowadays considered as being on the rise to a full and well-developed subschool of realism (Wohlforth, 2016, p. 39), by some scholars it is described as only a kind of analytical distinction and not a coherent theoretical school or an independent research programme (Legro, Moravcsik, 1999, pp. 5-55). The NCR's adherents have been developing a very complex theoretical picture of the international system and its pressures being transformed by domestic variables. However, there are a myriad of the intervening variables that have been applied by different NCR's advocates which make the theory being described as a kind of non-falsifiable 'pick and choose' strategy. For instance, William Wohlforth (1993) stressed that the decisions are influenced by political leaders' perceptions of relative power, whereas Stephen M. Walt $(1987 ; 2002)$ was focused on the perception of intent. Randall Schweller (1998) referred to state motivations and Jervis (2005) to states' costbenefit analysis in economic and security affairs. Additionally, some neo-classical realists underlined the importance of the political tradition as well as identity of political elites (Friedberg, 2000; Monten, 2005) together with the implications of dominant interpretations of national history and perception of the nation's past (Mouritzen, Wivel, 2005). Moreover, they stressed the balance of power between domestic institutions (Zakaria, 1998) as well as the role of propaganda of domestic coalitions (Snyder, 1991). Michael C. Desch (1999) focused on the very specific relationship between the threat environment and civil-military relations and Sten Rynning together with Stefano Guzzini (2001) underlined the importance of the change within military doctrines. All of these variables not only show that the link between the system and the foreign policy choices is very complex, but also make evident their plurality and variety. All of them are able to explain dependent variables, however the majority of them can encompass just a set of specific foreign policy decisions and not patterns of outcomes within the international system (Lobell et al., 2009). This has led to at least two types of criticism formulated against 'the newest realism'.

Firstly, as Schweller (2003) pointed out, the specific foreign policy decisions can be uncovered only through detailed case studies and as a consequence the 
NCR analyses are frequently accused of offering only a collection of ad hoc (and according to some scholars even post hoc) arguments based on a single case or very few selected case studies. This has led many IR scholars to face a very difficult choice between seeking parsimony or logical elegance and complexity (or contextual subtlety). Some theoretical opponents have also suggested that formulating of post hoc arguments has resulted in developing a degenerative research paradigm' that has lost its distinctiveness vis-à-vis traditional and newly formulated theoretical alternatives - like liberalism or social constructivism. As Jeffrey Legro and Moravcsik (1999, pp. 5-55) suggested, post hoc efforts to explain neorealist anomalies have resulted in paradigmatic incoherence and indistinctiveness. ${ }^{6}$ Moreover, while developing his neoclassical realist's assumptions, Schweller (2004) pointed out, that 'whether states [choose to] balance against threats is not primarily determined by structural-systemic factors' but rather, like all decisions , 'by the domestic political process' (Schweller, 2004, p. 9). After this statement, which is de facto not a strict neorealist claim, he focused on three main variables: elite cohesion, social cohesion and government stability. When all of them are high, political elites reach consensus on foreign policy and consequently respond appropriately to systemic pressures - which means that they decide to continue or change the state's foreign policy. When one or more of the above mentioned variables declines, the state is being paralyzed and cannot react in an appropriate way - which means that the state underbalances. By introducing this set of domestic variables Schweller has in fact redefined the realist concept of 'capability' that is crucial for this theory, but as far as he treats them as exogenously given, the structural realists might forgive him. Yet, another problem of his proposition lies in the distinction between revolutionary and non-revolutionary states, which according to him are functionally differentiated. And that is a violation of one of core neorealist assumptions, because Schweller stressed that it is ideology what motivates revolutionary states - which is in fact another intervening variable. This locates variation in states' behaviour within domestic preferences without discussing their origins what makes the Schweller's argument ad hoc, as he did not even link the role of ideology with mobilization of states resources or with one of his three variables, what would certainly improve his idea (Narizny, 2017, p. 173). This kind of explanation of states' behaviour is definitely a combination of two different theories: one is the systemic one and second is the domestic level one,

One has to stress here that, according to Brian Rathburn (2008, pp. 294-321), realists have not fought back these arguments. They did not admit that in fact they are bound by a certain logic in their approach and stressing the 'hard core' of its paradigm. See: St. Walt (1997, pp. 931-935), Thomas J. Christensen and Jack Snyder (1997, pp. 919-926), Schweller (1997, pp. 927-930). 
but as a result we do not get an aggregate effect but rather two inadequately integrated theories.

Secondly, this version of realism is under siege because of some, above signalled, theoretical inadequacies which are of paramount importance for those who attempt to develop a new kind of research programme or a new version of neorealism. As it has been mentioned before, the theory proposed by Waltz has been frequently described as being too elegant and at the same time too parsimonious - as the author famously stressed, 'structures tell us a small number of big and important things' (Waltz, 1986, p. 329). This statement is however regularly misinterpreted and has consequently resulted in accusing Waltz's conception of being underspecified. As Ole Wæver reasonably suggested, almost all theories are underspecified but that is why they are 'sparse in formulation and beautifully simple' (Wæver, 2009, p. 212). The specification comes when we are trying to test the theory or simply apply it. The idea of incorporating as many intervening variables as possible in order to get more specific picture of reality without a clear instruction about how to do it might consequently lead to serious errors. Moreover, it is in contradiction with the Waltz's idea of theory, who frequently stressed that theory is a mental picture or a creative idea that helps to explain general laws. Therefore, following this way of thinking, theories can only be invented and not discovered. Moreover, theories have to be abstract and distanced from the real world in order to be able to explain it. Neoclassical realists, by adding different variables to the idea of Waltz, are in fact against him and are becoming unable to keep their adherence to assumptions formulated by him. Instead, by adding more and more intervening variables, they are creating a kind of 1:1 model of reality and not a theory. I am in favour of Wæver's argument that this way of theory building (no matter if we are in favour of this theory building strategy or not) is at odds with the Waltz's proposition, therefore it is difficult for the NCRs to emphasize that they have adopted his ideas regarding the role of the structure. What is more, they are not explaining how and to what extent they accept his ideas. Most of the works, described as applying neoclassical realism, take for granted the assumption that the international system structure constrains states' behaviour and test only the second part of the theory proposed by them. That means that the authors are focused only on the second part of their proposal (the part involving the role of intervening variables) and not on the combination of variables operating at different levels of analysis.

Apart from all weaknesses of neoclassical realism, one of its strengths is an applicability to analyze foreign policy mainly due to adopting unit level variables what more parsimonious theories cannot do. Yet, that makes the NCR a theory of foreign policy and not a theory of international relations, but we have to bear in 
mind that although Waltz stressed that these are two different kind of theories, he in fact did not refuse the foreign policy theories. ${ }^{7}$ This is, however, also the main challenge of the NCR - to combine systemic pressures with unit level variables is such a way as to provide them with explanatory power. Additionally, one has to combine them without ignoring the ideational character of many of domestic factors. All these challenges will be discussed in following parts of the text which also aims to answer the research question formulated in the first paragraph.

\section{FPA - a theory without a chapter}

In the title of his famous article from 1996 Waltz stressed that 'International politics is not foreign policy' and in this way confirmed the very clear separation between IR and FPA. ${ }^{8}$ Since its inception in the 1950s, ${ }^{9}$ FPA has been developed separately from the mainstream IR theories and excluded itself from the IR discipline. ${ }^{10}$ Its theoretical ground has been human decision makers who act singly or within groups and as a result the particularities of the human beings have been perceived as vitally important to understanding foreign policy. ${ }^{11}$ It has resulted in the most distinguishing feature of FPA, namely its classification by unit

Waltz just excluded domestic attributes from his theory and stressed that the [neorealist] theory explains why states similarly placed behave similarly despite their internal differences. The explanation of states' behaviour is found at the international, and not at the national, level. That is why the theory is called a theory of international politics. In contrast, a theory of foreign policy would explain why states similarly placed in a system behave in different ways. Differences in behaviour arise from differences of internal composition. Foreign policies are governmental products (Waltz, 1996, pp. 54-55).

8 Wendt also stressed that he is (like Waltz)' interested in international politics, not foreign policy' and in this way, with reference to David Houghton's and William Flanik's opinion pointed out that FPA is 'a theory without a home', 'treated indifferently by nonpractitioners and lacks its own chapter in most IR books'. See: Houghton (2007, p. 26) and Flanik (2011, p. 423).

$9 \quad$ It has to be mentioned here that the term 'foreign policy' has been the subject of reflection for more than two thousand years - from Thucydides. Gunther Hellmann and Knud E. Jørgensen (2016, p. 7) stressed that foreign policy, defined in terms of the pursuit of external interests by sovereign states, emerged after the Treaties of Westphalia in 1648. It came to the increasing use in $18^{\text {th }}$ century, when first ministers of foreign affairs became members of governments. Their activity became the subject of reflection or commentary that was not only technical (qualities of skilled diplomacy), but also political (results of foreign policy). The first publication that had in its title the phrase 'foreign policy' was published in 1936 in Great Britain (see: Haliżak, 2018, pp. 13-61).

10 For more about this division see: Kaarbo (2015, pp. 189-216) and Pietraś (2018, pp. 165-213).

11 According to the opinion of Hudson (2005, p. 2), which has dominated FPA theorizing, 'the explanandum of foreign policy analysis includes the process and resultants of human decision making with reference to or having known consequences for foreign entities'. 
of analysis, the actor-specific sources of foreign policy. Consequently, the process of foreign policy decision making has become as important as its outcome and this still continues to be the distinctive feature of FPA. It is also worth noting that during the time of its development, FPA was boxed under political science branch of public policy and not under the IR. ${ }^{12}$ This separation has been additionally organizationally confirmed by different journals or conferences focused on either foreign policy or IR. ${ }^{13}$ This lack of true engagement between the IR theoreticians and the FPA researchers was confirmed in 2005 by the establishment of Foreign Policy Analysis - a journal that offers a distinctive or even alternative debate on issues that are outside the IR debate. I argue that this separation might be overcome and FPA and IR might be perceived as complementary, especially after the period of a so called 'domestic turn' within IR. Moreover, following Walter Carlsnaes, I claim that FPA is a subdiscipline of IR..$^{14}$ According to this author, almost all foreign policy analysts today do agree 'that they belong squarely to the scholarly domain of IR rather than to any of the policy sciences' (2010, p. 331), however some of them are also aware of quite opposite opinions even within the Polish academia (Kuźniar 2018, pp. 177-184) ${ }^{15}$ Moreover, IR scholars have been also associated with the foreign policy analysis, especially from the inception of the discipline that was dominated by realist paradigm and analysis of states' behaviour. That is why Sten Rynning together with Stefano Guzzini (2001, p. 2) asked, 'what else, if not analyzing foreign policy, had a large bulk of scholars been doing?' before the inception of FPA. One might assume that they had in mind the IR scholars, who have been interested in states' foreign policies, especially during that times when the international system was dominated by sovereign actors.

The history and evolution of FPA clearly show that from its beginnings in the 1950s, the research community was focused on the grand theory building that dominated theoretical reflections during two decades. Three paradigmatic works

12 The division between FPA and IR was showed quite clearly by the publication of the chapter 'Foreign Policy' in the volume on 'Policies and Policymaking' and not in 'International Politics' in the volume 'Handbook of Political Science' issued in 1975 (see: Cohen, Harris, 1975, pp. 381-437).

13 Nonetheless, for some scholars this separation has always been unnecessary. In a field that is itself only a subdivision of political science, increasing specialization may lead to confusions, closed discourses within different subdisciplines and intellectual entropy.

14 It has to be also mentioned here that James Rosenau (1976, p. 370, as quoted in Korany, 1986, p. 42) as well as Charles Kegley and Richard A. Skinner (1976, p. 303, as quoted in Korany, 1986 , p. 42) in the 1970s suggested that the comparative study of foreign policy has emerged as 'normal science in the Kuhnian sense'.

15 Some scholars suggest that foreign policy analysis is a domain of states and therefore belongs to the same extent to Political Science as to International Relations (Kuźniar, 2018, p. 178). 
laid the foundation of FPA, namely Richard Snyder and his colleagues' $(1954,1962$, 2002) publication focused on decision making processes; Rosenau (1974) on comparative foreign policy (CFP) and Harold and Margaret Sprout (1956) on the psycho-social milieu of foreign policy decision making (FPDM). They were the first generation of scholars working within FPA with tremendous enthusiasm. This period was characterized by great strides in conceptualizations as well as big efforts in data collection (Hudson, 2016, p. 17). Consequently, many of the first-generation scholars adopted quantitative, positivist model of theory building. The second wave of theorizing started in the late 1970s. It was a period of critical self-reflection dominated by deliberations and tensions between the desire for hard-sciencelike grand theory and the assumptions that micro-level detailed explanations are also necessary. The works published during that time (mainly between 1974 and 1993) were focused mostly on: small-group decision making (Janis, 1982; Semmel, Minix, 1979; Tetlock, 1979; Breslauer, Tetlock, 1991); organizational process and bureaucratic politics (Allison, Halperin, 1972; Halperin, Kanter, 1973); comparative foreign policy (McGowan, Shapiro, 1973); psychological influences on foreign policy decision making (Hermann, 1970; 1978; Hermann, Kegley, 1994; Jervis, 1976; Walt, 2002) as well as societal context (Putnam, 1988; Kaarbo, 1993; Skidmore, Hudson, 1993; Hagan, 1993). ${ }^{16}$ During the time of self-reflection, FPA scholars had to deal with two big dilemmas between: parsimony or micro-level details and qualitative or quantitative research. Additionally, CFP dwindled in the 1980s, since it did not fulfil its promises and the expression 'comparative foreign policy' started to sound rather naïve. Finally, FPA scholars decided to stay focused on middle-range theories considering them as complementary to the mainstream IR theories, especially after the fall of the Iron Curtain. As Hudson (2016, p. 30) lucidly articulated, 'as FPA was being liberated from its inconsistencies in the late 1980s, the world was being liberated from the chess match of the Cold War'. Actually, the actor-general theory was more appropriate during the Cold War, when states were considered as black boxes and de facto little was known of the closed communist regimes. It corresponds with the idea of James L. Ray that the most appropriate way of understanding 'levels of analysis' is to consider them as different social entities. Consequently, also IR scholars should not focus on the structural level only, but instead see how different levels of analysis (characterized as social entities) influence different aspects of analyzed reality. ${ }^{17}$

16 Hudson classified them as the second-generation of the FPA scholars, however Laura Neack, Jeanne A.K. Hey and Patrick J. Haney (1995, p. 3) have counted them as representatives of the first generation who remained outside the CFP paradigm.

17 This periodization is proposed by Hudson, however one has to stress there are also other publications offering different classifications of the FPA historiography. See: Smith (2012), Neack, Hey, Haney (1995). 
Polish publications quite often touch the topic of the foreign policy analysis (Pałyga, Symonides, 1978; Kostecki, 1988; Pietraś,1998; Łoś-Nowak, 2000), however most of them are related to determinants of the Polish foreign policy, the place of Poland in the international system or its role among the most influential international organizations. The question of theorizing foreign policy is still of relatively little importance and within the Polish academic discourse FPA remains 'a theory without a chapter' or a body of microtheories that are not anchored in any theory of IR (Houghton, 2007, p. 26). It has to be, however, mentioned here that recently some very important works focused on the foreign policy theorizing have been published. The work of Tomasz Pugacewicz (2017) and a publication edited by Edward Haliżak (2018) have to be highlighted. Currently, FPA is a sub-discipline of International Relations that is not only gaining increasing popularity among researchers but also, having its own theoretical and methodological basis, shows considerable research potential. Of course, as a distinct research area, it retains its characteristics or commitments like: to look below the nation-state level of analysis; to build middle-range theories; to pursue multicausual explanation spanning multiple levels of analysis; to utilize theory and findings from across the spectrum of social science and to view the process of decision making as being at least as important as its outcome (Hudson, 2016, p. 30). As one can easily see, some of the features of FPA bring it close to eclectic scholarship defined by Sil and Katzenstein. This argument will be also developed in the following part.

\section{The domestic variables' return as a theoretical challenge}

According to the realist paradigm, power rivalry is the most important factor determining world system politics, where states (viewed as unitary and rational actors) still play a major role. The main focus of these unitary and rational actors is their national security which they are aiming to protect by using the balance of power strategy or by the expansion politics. The two mentioned strategies help to distinguish between 'defensive' and 'offensive' variant of neorealism. The first one argues that the anarchic nature structure of the international politics encourages states to act defensively and balance power in order to maximize security, whereas the second one assumes the anarchic structure to lead states to maximize security by maximizing power - as the most powerful states are the most secure. Therefore, power still remains the key concept of realism. However, as it has been mentioned above, this 'highly abstract and purely structural-systemic theory' (Schweller, 2003, p. 345) cannot explain why states are acting differently, although being under the same structural pressure. 
Neoclassical realism, in order to answer this question, has significantly changed from its predecessor and focused on domestic politics as well as decision-making factors and processes. What is more, the above mentioned question might be also answered by using the domestic variables and explanations that are classic for FPA. That is why, FPA research is repeatedly described as kind of complementary to IR theory. Nevertheless, one has to mention that FPA researchers frequently criticize the NCR for its underdevelopment of domestic political and decision-making factors (Kaarbo, 2015, p. 204). According to the opinion of Brian Rathburn (2008, pp. 294-321), ideas and domestic politics are mentioned by the NCR in a very limited way. Firstly, the domestic variables are still treated as intervening conditions influencing political leaders' reaction to systemic pressures. This is however not accurate from FPA perspective which perceives domestic factors as equal to or sometime even more important than international ones (Kaarbo, 2015, p. 204). Secondly, neo-classical analyses of world politics frequently focus on a group of domestic variables however without justifying why some domestic factors are chosen over others.

Therefore, the main challenges of the NCR's foreign policy analysis are related to the possible blend of different levels of analysis as well as different kinds of factors defined as intervening variables. The first challenge is a possible combination of the structural factors with domestic variables without ending up with a set of post hoc arguments. The second challenge is about how to mix materialist factors like power with domestic variables that are not objectively measured and focused on processes of interpretation or perception ${ }^{18}$ (Wivel, 2005, p. 357). It has to be also pointed out here that almost all of IR theories use domestic factors as it was mentioned i.e. by Kaarbo (2015), however the difference between them is in the question how they use them. They cannot just add them to the core assumptions of paradigm, but should embed them in their axioms. Therefore, the inclusion of domestic variables or ideas is not inappropriate for realism, however it is of paramount importance to do it without going beyond the bounds of the paradigm (Rathburn, 2008, p. 304). In the following sections of this part of the article, I am going to discuss how some variants of the NCR are trying to deal with the above mentioned challenges. I will focus on the balance of threat theory proposed by Walt as well as on the Wohlforth's assumptions regarding the role of perception.

The first challenge is related to the level of analysis, however one has to stress that it is the NCR which made it possible to recognize that both systemic and unit levels of analysis together might offer a better explanation of world poli-

18 These two problems are also discussed within the academic discourse and mentioned by some critics of the realist paradigm. See: Legro and Moravcsik (1999, p. 6), Vasquez (1997) as well as Guzzini (2004). 
tics. They should not be treated as mutually exclusive, but rather as intertwined to design cumulative and progressive research programmes (Goldgeier, Tetlock, 2000, p. 88). According to Anders Wivel, this problem can be solved by specifying the policy-contingency framework in a more precise way and consequently show how resources (and systemic pressures) affect state's behaviour. This will help to avoid the choice between parsimony and complexity, because complexity is going to be gradually added in order to develop the explanatory power of the theory. The process of going more and more complex starts with the universal assumptions of the neorealist theory (1) which lead to the more specific assumptions related to the international system and its actors (2). Finally, the systemic constraints of those actors are identified and their effects on domestic politics are defined (3). As Wivel pointed out, this is the way of moving from the general theory to specific foreign policy explanations and a complete realist explanation of world politics should include all the three stages, however some scholars are focused on one over the other (2005, p. 363). As a consequence, this process will help us to explain 'why state X made a certain move last Tuesday' as well as to predict 'the consequences of this move for state $\mathrm{X}$ by applying the logic of the theory to state Y and Z' (Waltz, 1979, p. 121, cited in Wivel, 2005, p. 363). This is showed in the Walt's balance of threat theory, one of the strongest addition to the structural realism that modified the balance of power theory. ${ }^{19}$ According to the author, states associate their own security with perceived threats and consequently try to balance through international relations. The perception of threat is determined by four main variables: aggregate power, geographic proximity, offensive power and aggressive intensions. As Wivel pointed out, some of these variables fit to the realist assumption, but some of them, like geographic proximity or perceptions of intents, do not. That is why, we should not only ask, why this set of variables has been chosen (although historical experience or ideology might be seen as much important), but also which of them should be applied firstly and why. The hypotheses proposed by Walt $(1985, \mathrm{p}$. 4) showed that in order to enter an alliance, 'states may either balance (ally in opposition to the principal source of danger) or bandwagon (ally with the state that poses the major threat)'. His proposition is defensive, as he pointed out that states usually prefer security to power. However, according to him, bandwagoning might be an offensive strategy, when a state enters an alliance with the most powerful source of threat, whereas balancing might be perceived as a defensive strategy. That is the most significant characteristic of this theory. Balancing and bandwagoning

19 The theory was firstly proposed in an article titled Alliance Formation and the Balance of World Power, published in the journal International Security in 1985 and later further elaborated in the book The Origins of Alliances in 1987. 
are described as responses to threat that states may pose, however the level of the threat is affected by the four variables mentioned above. The aim of this paper is not to explain the balance of threat theory, therefore I will not explain the hypotheses proposed by Walt, but focus on the selection of variables proposed by him. According to the proposition of Wivel, in order to explain state's behaviour we should apply one element (one set of the variables) of the theory and if it does not explain state action, take another. Nonetheless, Wivel does not specify what he classifies as a first set of variables and what as a second etc., consequently, following his logic, we do not know what variable should be applied first. Referring to his proposition, one may assume that we start from the systemic pressures and then go to domestic politics factors - in this case the role of perception, which I claim is the most significant element of the Walt's theory and which has been studied also by FPA scholars, is strongly emphasized. As history has showed, wrong perception of the state that might be viewed as a source of threat might result in a chain of political mistakes that was proved for instance by the misperception of Iraq's threat. The relations between power and its perception (or misperception) lead to the second challenge, namely, a possible combination of material and ideational factors is going to be solved by applying some FPA research.

As it has been mentioned above, adherents of the NCR do focus on perceptions, beliefs or political leaders' motives, however while comparing it with FPA tradition of research on this topic, this focus according to the NCR still remains underdeveloped. As James Goldgeier and Philip E. Tetlock showed (2000; 2001), the representatives of realist paradigm (now represented by neo-classical realists) should pay more attention not only to perception, beliefs and motives, but also to their origins. In his earlier work Goldgeier (1997, p. 141) stressed that Walt after analyzing some ideational domestic factors leaved the origins of them to a case-by-case empirical study that is absolutely insufficient for those who want to focus not on post hoc arguments, but on identifying long-term political processes. Wivel also proposed three possible ways of mixing material and ideational factors. As he pointed out, realists do not dismiss ideas influencing the actions of policymakers, however they have huge problems with integrating them into their analytical framework. Usually, they do this by using empirical caseby-case studies and consequently are being accused of formulating post hoc arguments only. The three proposed ways might be located on a continuum with the solution applying non-materialist variables in the most limited role on the one side and the solution applying ideas in the most expanded role on the other.

First, realist can focus primarily on material incentives while analyzing states' foreign policy and then pay attention to perceptions or motives in order to explain what is not explainable by materialist variables (Wivel, 2005, p. 369). According to the author, this was almost perfectly showed in Walt's application 
of his theory. He explained the lack of stable coalition against the US in the contemporary world politics by using firstly materialist factors (like the relative geographic isolation, the lack of offensive power of the US as well as deterrent capabilities of other states) and afterwards the ability of the US to show that it is not trying to acquire additional territory. The most important in this type of mixing materialist and ideational factors is the question - to what extent we are able to explain the states' foreign policy by using material variables and when we need to use non-material ones. For instance, in order to explain the US response to the terrorist attack after 11 September, 2001 one has to analyze firstly material costs of American power and then non-material cost of its international engagement that might by reduced only by making the American power and policy more acceptable for the rest of the world. The last part of this kind of analysis is possible only by referring to non-material factors as well as their origins and roots.

Second, realists have to ask how materialist and idealist variables interact and how they influence all the foreign policy decision making processes. A very good example of this way is the work of Wohlforth focused on the experiences of the US and the Soviet Union during the Cold War. The author referred to the role of perception, however in some kind different way than Walt, who (also according to Wivel) perceived it as a kind of auxiliary element needed for power analysis used only when materialist factors seemed to be insufficient. Wohlforth showed how perception mistakes might lead to wrong foreign policy decisions. According to him, the end of the Cold War should be perceived as a chain reaction to, sometimes inaccurate, the perception of power. The Wohlforth's analysis showed very clearly that the nature of material power cannot be easily separated from the nature of its perception and consequently the state's power cannot be solely treated as the most important, independent variable determining its behaviour. After analyzing Soviet and US perceptions of the balance of power during the Cold War, Wohlforth showed how perceptions of power influenced superpowers behaviour. He pointed out that power is a very difficult to define concept and it is almost impossible to separate it from (sometimes flawed) perceptions. Therefore, one may assume that he called in question the idea of real power. Moreover, he stressed the importance of perceptions and difficulties in their measurement and identification. Additionally, the author stressed the difficulties of 'sorting out opportunities from more genuine articulations' (1993, p. 30). His assumptions focused on power and its perceptions are frequently perceived as a kind of map for realist foreign policy analysis that resulted in his strong conviction that FPA and the IR theory should be pursued cumulatively.

Third, the last way of a possible combination of materialist and ideational factors is to ask about the micro-foundations of realism. This might be realized differently - either by using the motivational assumptions that already 
exist within realist paradigm (like emphasis on self-interest), or by using motivational assumptions from other disciplines: political science or those located outside, like evolutionary theory. However, one has to stress that the last one is heavily disputed within the IR discipline. The adoption of assumptions borrowed from political science might be a very good solution that will consequently allow explaining why states choose one strategy over another by using e.g. behavioural decision theory, game theory or prospect theory (Kahneman, Tversky $1979 ; 1984)$ that have their roots also in psychology. Prospect theory clearly explains under what conditions decision makers might be more likely to take risks. In addition, Tetlock and Goldgeier (2001) showed that literature in psychology should be of great interest to all IR scholars who represent macrolevel theories. In order to explain broad contours of international behaviour, IR scholars should pay much more attention to issues of misperceptions, possibility of errors in statescraft or social and market forces that can either strengthen or attenuate deviations from rationality (2001, pp. 71-77).

Also the above mentioned prospect theory might additionally help in explaining the difference between offensive and defensive realists who paradoxically differ mostly not about system, but unit-level factor. According to Goldgeier and Tetlock (2001, pp. 70-71), 'when states are in the domain of losses (e.g. Germany in 1939, Japan in 1941) they are more likely to take the irredentist approach that Mearsheimer posits [...]. When states are in the domain of gain, they are more likely to accept the status quo, as Waltz would predict'. A very similar opinion is shared by Glenn Snyder (2002, pp. 154-155), who showed that the difference between offensive and defensive realism in the question about how much security states desire. As anarchy does not offer any answer, we have to wonder under what circumstances states would choose a given strategy. Consequently, following the NCR, we focus on the role of elite consensus or barriers to mobilization that might affect the states' responses to systemic pressures.

Therefore, as it has been pointed out, it is now time for IR scholars to take advantage of psychological factors that have been already adopted by FPA research since the publication of the previously mentioned influential book of Snyder, Bruck and Sapin $(1954 ; 1963$; reprinted in 2002). Snyder together with his colleagues emphasized decision making processes and as numerous scholars have echoed this theme, the psychological approach remains still in a dominant position even after the 1990s. Publications of Freyberg-Inan, Harrison and James (2009) or Edelstein (2002) present research based on psychological assumptions regarding the importance of beliefs about others' intentions. Therefore they offer an essential aspect of subjectivity that is missed by many adherents of the NCR. They are not too reductionist, as many realists claim, but have the ability to reinforce arguments of a given theoretical IR tradition. Consequently, IR theorists 
should consider how environment and cognition or perception act in systematic patterns resulting in variation of world politics. As it has been showed, although the NCR is still wedded to anarchic international system as an independent variable and additionally marked by many theoretical flaws, it is still possible to develop its theoretical depth by borrowing from FPA. What I am trying to point out is that although neoclassical realism has made some promises that have been unfulfilled, there is still a possibility of mixing unit level variables with systemic pressures i.e. by referring to the analytical eclecticism.

\section{Conclusion}

Valerie Hudson (2007, p. 184), one of the most prominent FPA scholars, pointed out that 'as the field of FPA was first being formed, the goal of theoretical integration was put forward as an essential task' Since its inception FPA has engaged with different topics and literature related to i.a. public choice theory, political psychology or cognitive theory that has consequently made the FPA research eclectic and interdisciplinary. Insights from many disciplines are therefore useful for foreign policy analysts while explaining a myriad of diverse decisions. As it has been mentioned above, the explanandum of FPA includes the processes and resultants of human decision making, nonetheless the most important hallmark of FPA is the explanans which includes all the factors influencing decision making and decision makers. As a consequence, FPA is not only eclectic (or integrative) and interdisciplinary, but also multifactorial (as it looks for diverse factors influencing decision making processes) and multilevel (as it looks for variables located at different levels of analysis). Moreover, analysis of foreign policy has had no reason to increase competition between theories; FPA scholars, in order to understand all the possible policy dilemmas from many different angles, naturally gravitate towards the opinion that theories are rather complementary than competitive. This attitude has made FPA the most integrative theoretical enterprise of all the IR subfields.

By contrast, most of IR theories have been written as a response to realism and the discipline has been always marked by disputes between representatives of the most influential paradigms. Consequently, some IR scholars started to ask why 'isms' are evil and pointed out that we really do not need to organize in 'sects' anymore. Thus it seems that one of the most important values that FPA might offer to the whole discipline is the engagement in theoretical dialogue with the IR theory. As Wohlforth (2012, p. 51) pointed out in a brilliant way, borrowing an idea from Isaiah Berlin (1953) - 'the fox knows many things, but the hedgehog knows one big thing'. According to Wohlforth's advice, 
we should act as foxes, knowing different things, using different sources and in this way be better at practical tasks like FPA. What is more, being realist does not mean that one has to be inevitably a hedgehog believing that only anarchy constrains state's behaviour. On the contrary, since its inception the neoclassical realism has adopted several assumptions that are related to human beings and their motivations as well as many other factors seriously analyzed by FPA scholars. Borrowing from FPA could make realist analyses deeper and more sophisticated. Additionally, it might be also a kind of movement toward analytical eclecticism by applying such a two-stage approach that will fulfil all the premises of eclectic scholarship.

Unquestionably, it is extremely difficult to study both realism and foreign policy problems, however it is not impossible, especially for those realists who assume that realism is not a universal theory applying to many different conditions without alternation. In order to borrow from FPA, realists have to recognize the contingent nature of their theory, as some of neoclassical realists have already done. That opinion results in a kind of paradox defined by Wohlforth (2012, p. 51) - 'one can be very critical of academic realist theory and yet still find realism very useful in FPA. However, by introducing FPA studies into IR we might be able to integrate not only different levels of analysis, but also material and ideational factors, however as this article has elucidated - the task is quite difficult and marked with many flaws. Additionally, we (as IR scholars) might be also able to change our assumptions about rationality being replaced by thicker accounts informed by psychology (Hudson, 2007, p. 209).

As I have tried to show, FPA has continuously introduced to the IR new concepts or ideas, referring especially to domestic or psychological factors and drawing the attention to unit level and subjective variables. That has also resulted in changes within methodology, because of employing middle-range theories that have been classic to FPA since the 1970s. However, in order to maintain its status as an innovative subdiscipline of IR, FPA has to be permanently engaged with the theoretical or even philosophical dialogue. What is more, FPA should also explore issues that have been discussed within IR, like themes of change or globalization in order to maintain this relation mutually beneficial. As Hudson (2007, p. 209) pointed out, the quest for theoretical integration between FPA and IR has always been always elusive, but this quest might shape the future of the discipline. As it has been mentioned in the introduction, FPA theory intersects not only with the NCR's assumptions, but also with social constructivism, liberalism or even critical theory. 


\section{References}

Allison, G.T., Halperin, M.H. (1972). "Bureaucratic Politics: A Paradigm and Some Policy Implications". World Politics, 24 (Supplement), pp. 40-79.

Berlin, I. (1953). The Hedgehog and the Fox: An Essay on Tolstoy's View of History. London: Weidenfeld \& Nicolson.

Bieleń, S. (2010). Polish Foreign Policy after Joining the NATO and the EU: Problems of Identity and Adaptation. Warsaw: Difin.

Breslauer, G., Tetlock, P.E. (1991). Learning in US and Soviet Foreign Policy. Boulder, CO: Westview Press.

Carlsnaes W. (2002). "Foreign Policy”. In: W. Carlsnaes, T. Risse, B. Simmons (eds.). Handbook of International Relations. London: Sage.

Christiansen, Th.J. (1996). Useful Adversaries. Princeton, NY: Princeton University Press.

Christiansen, Th.J. (1997). "Progressive Research on Degenerate Alliances”. The American Political Science Review, 91(4), pp. 919-926.

Cohen, B.C., Harris, S.A. (1975). "Foreign Policy”. In: F.I. Greenstein, N.W. Polsby (eds.). Handbook of Political Science. Reading, MA: Addison-Wesley.

Desch, M.C. (1999). Civilian Control of the Military. Baltimore, MD: Johns Hopkins University Press.

Dunne, T., Hansen, L., Wight, C. (2013). “The End of International Relations Theory?”. European Journal of International Relations, 19(3), pp. 402-425.

Edelstein, D.M. (2002). "Managing Uncertainty: Beliefs about Intentions and the Rise of Great Powers”. Security Studies, 12(1), pp. 1-40.

Flanik, W. (2011). "Bringing FPA Back Home: Cognition, Constructivism, and Conceptual Metaphor." Foreign Policy Analysis, 7(4), pp. 361-447.

Fordham, B.O. (2009). "The Limits of Neoclassical Realism: Additive and Interactive Approaches to Explaining Foreign Policy Preferences”. In: S.E. Lobell, N.M. Ripsman, J.W. Taliaferro (eds.). Neoclassical Realism, the State, and Foreign Policy. Cambridge: Cambridge University Press.

Foulon, M. (2015). “Neoclassical Realism: Challengers and Bridging Identities”. International Studies Review, 17(4), pp. 635-661.

Freyberg-Inan, A., Harrison, E., James, P. (2009). “Conclusion: Ways Forward”. In: A. Freyberg-Inan, E. Harrison, P. James (eds.). Rethinking Realism in International Relations. Baltimore: Johns Hopkins University Press.

Friedberg, A.L. (2000). In the Shadow of the Garrison State. New York: Princeton University Press.

Goldgeier, J.M. (1997). "Psychology and Security”. Security Studies, 4(6), pp. 137-166.

Goldgeier, J.M., Tetlock Ph.E. (2000). "Human Nature and World Politics: Cognition, Identity, and Influence”. International Journal of Psychology, 35(2), pp. 87-96. 
Goldgeier, J.M., Tetlock Ph.E. (2001). "Psychology and International Relations Theory”. Annual Review of Political Science, 4, pp. 67-92.

Guzzini, S. (2004). “The Enduring Dilemmas of Realism in International Relations”. European Journal of International Relations and Development, 10(1), pp. 533-568.

Hagan, J.D. (1993). Political Opposition and Foreign Policy in Comparative Perspective. Boulder, CO: Westview Press.

Haliżak, E. (2018). “On the Essence of Foreign Policy Analysis”. In: E. Haliżak (ed.). Research in Foreign Policy. Warsaw: Rambler.

Haliżak, E. (ed.) (2018). Foreign Policy Analysis. Warsaw: Rambler.

Halperin, M.H., Kanter, A. (1973). Readings in American Foreign Policy: A Bureaucratic Perspective. Boston, MA: Little Brown.

Hellmann, G., Jørgensen, K.E. (2016). Theorizing Foreign Policy in a Globalized World. New York: Palgrave.

Herman, M.G. (1970). "Explaining Foreign Policy Behaviour Using the Personal Characteristics of Political Leaders". International Studies Quarterly, 24(1), pp. 7-46.

Herman, M.G. (1978). "Effects of Personal Characteristics of Leaders on Foreign Policy”. In: M.A. East, S.A. Salmore, C.F. Herman (eds.). Why Nations Act. Beverly Hills, CA: Sage.

Herman, M.G., Kegley, C.W. (1994). "Rethinking Democracy and International Peace”. Paper presented at the annual meeting of the American Political Science Association, New York, 1-4 September.

Houghton, D.P. (2007). "Reinvigorating the Study of Foreign Policy Decision Making: Toward a Constructivist Approach”. Foreign Policy Analysis, 3(1), pp. 24-45.

Hudson, V.M. (2005). "Foreign Policy Analysis: Actor-Specific Theory and the Ground of International Relations: Foreign Policy Analysis”. Foreign Policy Analysis, 1(1), pp. 1-30.

Hudson, V.M. (2007, 2014). Foreign Policy Analysis: Classic and Contemporary Theory. Plymouth: Rowman \& Littlefield.

Hudson, V.M. (2016). “The History and Evolution of Foreign Policy Analysis". In: S. Smith, A. Hadfield, T. Dunne (eds.). Foreign Policy: Theories, Actors, Cases. Oxford: Oxford University Press.

Janis, I.L. (1982). Groupthink: Psychological Studies of Policy Decisions and Fiascos. Boston, MA: Houghton Mifflin.

Jervis, R. (1976). Perception and Misperception in International Politics. Princeton, NJ: Princeton University Press.

Jervis, R. (2005). American Foreign Policy in a New Era. London: Routledge.

Kaarbo, J. (1993). "Power and Influence in Foreign Policy Decision-Making: The Role of Junior Parties in Coalition Cabinets in Comparative Perspective”. Paper presented at the annual meeting of the International Studies Association, Acapulco, Mexico, 23-27 March. 
Kaarbo, J. (2015). "A Foreign Policy Analysis Perspective on the Domestic Politics Turn in IR Theory". International Studies Review, 17(2), pp. 189-216.

Kahneman, D., Tversky, A. (1979). "Prospect Theory: An Analysis of Decision under Risk". Econometrica, 47(2), pp. 263-291.

Kahneman, D., Tversky, A. (1984). “Choices, Values and Frames”. American Psychologist, 39(4), pp. 341-350.

Katzenstein, P.J., Sil, R. (2010). "Analytic Eclecticism in the Study of World Politics: Reconfiguring Problems and Mechanisms across Research Traditions". Perspectives on Politics, 8(2), pp. 411-431.

Kirshner, J. (2010). “The Tragedy of Offensive Realism: Classical Realism and the Rise of China”. European Journal of International Relations, 18(1), pp. 53-75.

Korany, B. (ed.) (1986). How Foreign Policy Decisions Are Made in the Third World. Boulder, CO: Westview.

Kostecki, W. (1988). Foreign Policy: Theoretical Framework. Warsaw: PWN.

Kuźniar, R. (2018). "Book Review - Research in Foreign Policy ed. by E. Haliżak”. International Affairs, 2, pp. 177-188.

Legro, J.W., Moravcsik, A. (1999). "Is Anybody Still a Realist". International Security, 24(2), pp. 5-55.

Lobell, S., Norrin, E., Ripsman, M., Taliaferro, J.W. (2009). Neoclassical Realism, the State, and Foreign Policy. Cambridge: Cambridge University Press.

Łoś-Nowak, T. (2000). International Relations. Wroclaw: Wroclaw University Press.

McGowan, P., Shapiro, H.B. (1973). The Comparative Study of Foreign Policy: A Survey of Scientific Findings. Beverly Hills, CA: Sage.

Mearsheimer, J.J., Walt, St.M. (2013). "Leaving Theory Behind: Why Simplistic Hypothesis Testing Is Bad for International Relations". European Journal of International Relations, 19(3), pp. 427-457.

Monten, J. (2005). “The Roots of the Bush Doctrine: Power, Nationalism and Democracy Promotion in US Strategy”. International Security, 29(4), pp. 112-156.

Moravcsik, A. (1997). “Taking Preferences Seriously: A Liberal Theory of International Relations”. International Organization, 51(4), pp. 513-553.

Mouritzen, H., Wivel, A. (eds.) (2005). The Geopolitics of Euro-Atlantic Integration. London-New York: Routledge.

Narizny, K. (2017). “On Systemic Paradigm and Domestic Politics”. Security Studies, 42(2), pp. 155-190.

Neack, J., Hey, J., Haney P. (eds.) (1995). Foreign Policy Analysis: Continuity and Change in Its Second Generation. Englewood Cliffs: Prentice Hall.

Pałyga, E.S., Symonides, J. (1978). Theoretical Problems of Foreign Policy. Warsaw: IGKR SGPiS.

Parzymies, S., Popiuk-Rysińska, I. (2012). Poland's Participation in International Organizations. Warsaw: Scholar. 
Pietraś, M. (2018). “Foreign Policy Analysis and International Relations”. In: E. Haliżak (ed.). Research in Foreign Policy. Warsaw: Rambler.

Pietraś, Z.J. (1998). Decydowanie polityczne. Warsaw: Wydawnictwo Naukowe PWN.

Pugacewicz, T. (2017). Theories of Foreign Policy: American Foreign Policy Analysis Perspective. Cracow: Jagiellonian University Press.

Putnam, R. (1988). "Diplomacy and Domestic Politics: The Logic of Two-Level Games". International Organization, 42(3), pp. 427-460.

Rathburn, B. (2008). "A Rose by Any Other Name: Neoclassical Realism as the Logical and Necessary Extension of Structural Realism". Security Studies, 17(2), pp. 294-321.

Rose, G. (1998). "Neoclassical Realism and Theories of Foreign Policy”. World Politics, 51(1), pp. 144-172.

Rosenau, J.N. (1966). "Pre-theories and Theories of Foreign Policy”. In: B.R. Farrel (ed.). Approaches to Comparative and International Politics. Evanston: Northwestern Polity Press.

Rosenau, J.N. (1974). Comparing Foreign Policies: Theories, Findings, and Methods. New York: John Wiley.

Rynning, S., Guzzini, S. (2001). "Realism and Foreign Policy Analysis”. Copenhagen: Copenhagen Peace Research Institute, COPRI Working Papers 42.

Schweller, R. (1997). "New Realist Research on Alliances: Refining, Not Refuting”. The American Political Science Review, 91(4), pp. 927-930.

Schweller, R. (1998). Deadly Imbalances. New York: Columbia University Press.

Schweller, R. (2003). “The Progressiveness of Neoclassical Realism”. In: C. Elman, M.F. Elman (eds.). Progress in International Relations Theory. Cambridge: Cambridge University Press.

Schweller, R. (2004). "Unanswered Threats: A Neoclassical Realist Theory of Underbalancing”. International Security, 29(2), pp. 159-201.

Semmel, A.K., Minix, D. (1979). "Small Group Dynamics and Foreign Policy Decision-Making: An Experimental Approach”. In: L.S. Falkowski (ed.). Psychological Models in International Politics. Boulder, CO: Westview Press.

Skidmore, D., Hudson, V.M. (1993). The Limits of State Autonomy: Societal Groups and Foreign Policy Formulation. Boulder, CO: Westview Press.

Smith, S. (1986). “Theories of Foreign Policy: An Historical Overview”. Review of International Studies, 12(1), pp. 13-29.

Smith, S. (2012). “Theories of Foreign Policy: An Historical Overview”. In: W. Carlsnaes (ed.). Foreign Analysis, Vol. I-V. London: Sage, pp. 3-25.

Snyder, J. (1991). Myths of Empire: Domestic Politics and International Ambition. Ithaca, NY: Cornell University Press.

Snyder, G. (2002). “Mearsheimer's World - Offensive Realism and the Struggle for Security”. International Security, 27(1), pp. 149-173.

Snyder, R.C., Bruck, H.W., Sapin, B. (2002). Decision-Making as an Approach to the Study of International Politics. Princeton-New York: Palgrave Macmillan. 
Sprout, H., Sprout, M. (1956). Man-Milieu Relationship Hypotheses in the Context of International Politics. Princeton: Princeton University Press.

Taliaferro, J.W. (2006). "State Building for Future Wars: Neoclassical Realism and the Resource-Extractive State". Security Studies, 15(3), pp. 464-495.

Tetlock, P.E. (1979). "Identifying Victims of Groupthink from Public Statements of Decision Makers". Journal of Personality and Social Psychology, 37(8), pp. 1314-1324.

Vasquez, J.A. (1997). “The Realist Paradigm and Degenerative versus Progressive Research Programs: An Appraisal of Neotraditional Research on Waltz' Balancing Proposition". American Political Science Review, 91(4), pp. 899-912.

Wæver, O. (2009). "Waltz's Theory of Theory”. International Relations, 23(2), pp. 201-222.

Walt, St.M. (1985). “Alliance Formation and the Balance of World Power”. International Security, 9(4), pp. 3-43.

Walt, St.M. (1987). The Origins of Alliances. Ithaca, NY: Cornell University Press.

Walt, St.M. (1997). “The Progressive Power of Realism”. The American Political Science Review, 91(4), pp. 931-935.

Walt, St.M. (2002). "Revolution and War”. World Politics, 44(3), pp. 321-368.

Walt, St.M. (2002). “The Enduring Relevance of the Realist Tradition”. In: I. Katznelson, H.V. Milner (eds.). Political Science: The State of the Discipline. New York: W.W. Norton.

Waltz, K.N. (1979, 2010). Theory of International Politics. New York: McGraw-Hill.

Waltz, K.N. (1986). "Reflections on Theory of International Politics: A Response to My Critics”. In: R.O Keohane (ed.). Neorealism and Its Critics. New York: Columbia University Press.

Waltz, K.N. (1996). “International Politics Is Not Foreign Policy”. Security Studies, 6(1), pp. $54-57$.

Wivel, A. (2005). "Explaining Why State X Made a Certain Move Last Tuesday: The Promise and Limitations of Realist Foreign Policy Analysis". Journal of International Relations and Development, 8(4), pp. 355-380.

Wohlforth, W.C. (1993). The Elusive Balance. Ithaca, NY: Cornell University Press.

Wohlforth, W.C. (2012). "Realism and Foreign Policy”. In: S. Smith, A. Hadfield, T. Dunne (eds.). Foreign Policy: Theories, Actors, Cases. Oxford: Oxford University Press.

Zakaria, F. (1998). From Wealth to Power. Princeton, NJ: Princeton University Press. 